\title{
Effects of desiccation and freezing on vitality and field performance of broadleaved tree species
}

\author{
Kalliopi Radoglou* and Yannis Raftoyannis \\ Forest Research Institute, Vassilika, GR-57006, Thessaloniki, Greece
}

(Received 23 November 1999; accepted 15 May 2000)

\begin{abstract}
Seedlings of Acer pseudoplatanus L., Fraxinus ornus L. and Castanea sativa Miller., were exposed to desiccating conditions $\left(15{ }^{\circ} \mathrm{C}, 50 \% \mathrm{RH}\right.$, air movement $0.3 \mathrm{~m} \mathrm{~s}^{-1}$, photosynthetic active radiation $\left.350 \mu \mathrm{mol} \mathrm{m} \mathrm{m}^{-2} \mathrm{~s}^{-1}\right)$ and freezing $\left(-5^{\circ} \mathrm{C}\right.$, darkness). The effect of stress factors on seedling quality was assessed using root electrolyte leakage, water potential and moisture content of fine roots. After treatments, seedlings were outplanted in a field site. The effects of desiccation and freezing on planting stock quality and field performance varied and depended upon the length of exposure and species. Root electrolyte leakage values were significantly related to field performance rates of seedlings exposed to both stress factors. Root moisture content and root water potential were related to survival only in the case of desiccation treatment.
\end{abstract}

seedling quality / survival / planting stock / desiccation / freezing

Résumé - Effets du dessèchement et de la congélation sur la vitalité et la performance des plants d'espèces arborées platyphylles. Des plants d'Acer pseudoplatanus L., Fraxinus ornus L. et Castanea sativa Miller, ont été soumis à des traitements conditionnés contrôlés de dessèchement $\left(15^{\circ} \mathrm{C}, 50 \% \mathrm{HR}\right.$, mouvement d'air $0.3 \mathrm{~m} \mathrm{~s}^{-1}$, PAR $\left.350 \mu \mathrm{mol} \mathrm{m}^{-2} \mathrm{~s}^{-1}\right)$ et de congélation $\left(\mathrm{à}-5^{\circ} \mathrm{C}\right.$, dans l'obscurité). Les effets de ces facteurs de stress sur la qualité des plants ont été établis par la mesure de la perte relative en électrolyte, du potentiel hydrique et de la teneur en eau des racines fines. Après ces traitements, les plants ont été installés en plantation. Les effets du dessèchement et de la congélation sur la qualité et la performance des plants varient et dépendent du temps d'exposition et des espèces. Les valeurs de perte relative en électrolyte racinaire sont fortement corrélées aux niveaux des performances des plants exposés aux facteurs de stress. La teneur en eau des racines et le potentiel hydrique sont reliés à la survie seulement dans le cas du traitement de dessèchement.

qualité / survie / plants / dessèchement / congélation

\section{INTRODUCTION}

Reforestation is considered a task of prime importance in Greece and in recent years, the planting of indigenous broadleaved tree species has been promoted by the Greek Forest Service. Nonetheless, many trees die after outplanting and failures increase during the first five years after establishment. In such cases, poor performance may be attributed to low standards of planting stock, careless planting or adverse planting site conditions. Seedling quality varies due to inappropriate nursery, lifting and transportation practices. The effect of desiccation and frost damage on seedling survival has not been studied in Greece, although they may be major causes of planting failures. McKay [19] reviewed the effect of stresses between lifting and planting on nursery stock quality and performance and noted the importance of desiccation and freezing as the most common potential dangers in nursery operations.

In Northern Greece, air temperatures fall below zero quite often during January and February. Freezing

* Correspondence and reprints

Tel.+3031 461171; Fax.+3031 461341; e-mail: radoglou@spark.net.gr, radoglou@fri.gr 
temperatures may affect seedling quality as most lifting and planting is carried out during the winter months. McEvoy and McKay [16] reported on the effect of freezing on broadleaved species while many other authors on coniferous plants $[2,12,14,18]$. Bare-root stock is particularly vulnerable to freezing damage between lifting and planting when roots are not protected and the ambient temperatures are low, and since roots have a limited freezing tolerance compared to the shoot. Also, plants can be exposed to drying conditions at several stages during the process of lifting, handling, transportation and before planting. Many workers have studied the role of desiccation to seedling quality, most of them using coniferous plants $[1,4,7,14$, $23,24,26,27]$ although few of them used broadleaved species in their experiments $[6,8,16,22]$.

Planting stock quality is determined by morphological and physiological characteristics of seedlings and can be assessed before planting, using one of the many tests applied worldwide [3, 5, 23]. More recently, Mattsson [13] reviewed the seedling quality assessment methods used in predicting field performance and grouped them into morphological (height, stem diameter, shoot:root ratio) and physiological methods (electrolyte leakage, enzymatic activity, water potential, mineral nutrition). Although a lot of research has been dedicated to the role of seedling quality assessment prior to field planting, there is still a need to develop more reliable testing methods to predict field performance after outplanting, especially for broadleaved species and for environments such as the Mediterranean one.

In this study, we investigated the possibility of using plant vitality assessment methods (root electrolyte leakage, root water potential and root moisture content) as pre-planting indicators of seedling quality following desiccation and freezing treatments. We also measured survival and growth after outplanting in order to assess the field performance of tested plants and relate performance with pre-planting measurements.

\section{MATERIALS AND METHODS}

\subsection{Plant material and experimental design}

Nursery stock of three broad-leaved tree species, commonly planted in Greece, were selected for this study: two-year-old bare-root Acer pseudoplatanus L., (origin: Drama, Greece), one-year-old bare-root Fraxinus ornus L., (origin: Pente Vrises, Lagadas, Greece) and one-year-old, container grown Castanea sativa Miller, (origin: Petrokerasa, Lagadas, Greece). Seedlings were raised at the forest nursery of Lagadas, $25 \mathrm{~km}$ north of Thessaloniki $\left(40^{\circ} 38^{\prime} \mathrm{N}, 23^{\circ} 01^{\prime} \mathrm{E}\right.$, altitude $\left.100 \mathrm{~m}\right)$. The
Table I. Description of planting stock. Means and their standard deviation in parentheses.

\begin{tabular}{lccc}
\hline Plant & $\begin{array}{c}\text { Height } \\
(\mathrm{cm})\end{array}$ & $\begin{array}{c}\text { Length of } \\
\text { longest root } \\
(\mathrm{cm})\end{array}$ & $\begin{array}{c}\text { Root collar } \\
\text { diameter } \\
(\mathrm{mm})\end{array}$ \\
\hline Acer pseudoplatanus & $13.4(4.3)$ & $14.7(3.9)$ & $4.4(0.8)$ \\
Castanea sativa & $14.0(3.2)$ & $16.6(1.1)$ & $6.0(1.4)$ \\
Fraxinus ornus & $13.2(2.5)$ & $22.2(3.8)$ & $3.4(0.8)$ \\
\hline
\end{tabular}

nursery has a sandy loam soil type and is stone free. The mean annual rainfall is $480 \mathrm{~mm}$.

On 12th of January 1998, approximately 3500 plants for each species were lifted from the nursery beds, placed in black polyethylene bags and transported to the Forest Research Institute, Thessaloniki, Greece (transportation time: $1 / 2 \mathrm{~h}$ ). They were stored at $+4{ }^{\circ} \mathrm{C}$ until required, usually within 2 days. Although an effort was made during lifting to select uniform plants, a further detailed selection for uniformity was carried out inside the cold rooms in order to avoid desiccation stress. Morphological parameters of planting stock are shown in table I.

We carried out our controlled environment tests in an attempt to simulate desiccation and freezing damage before planting. Whole plants were laid horizontally on wire mesh, inside a controlled environment room $\left(15^{\circ} \mathrm{C}\right.$, $50 \%$ relative humidity $(\mathrm{RH})$, air movement $0.3 \mathrm{~m} \mathrm{~s}^{-1}$, photosynthetic active radiation (PAR) $350 \mu \mathrm{mol} \mathrm{m} \mathrm{m}^{-2} \mathrm{~s}^{-1}$ ) and subjected to desiccation for $0,1,3$ or $24 \mathrm{~h}$. Freezing treatments were carried out by placing whole plants into a controlled temperature room (preset at $-5^{\circ} \mathrm{C}, 90 \% \mathrm{RH}$, in darkness) for $0,3,24$ or 48 hours. Control plants were not subjected to any treatment and planted immediately after the vitality tests. After the desiccation and frost treatments were completed, the vitality of seedlings was immediately assessed.

\subsection{Vitality assessment}

Root electrolyte leakage (REL) was used to measure the physiological status of fine roots, before and after desiccation and freezing treatment, following the method described by McKay [17]. The leakage rate of undamaged control plants was measured to give baseline values. 15 seedlings for each species $\times$ treatment combination were used. Small amounts (100-300 mg, fresh weight) of fine roots $(<2 \mathrm{~mm}$ diameter $)$, were sampled from the midpoint of each root system. Roots were washed in tap water to remove soil and rinsed in deionized water to remove surface ions. The samples were placed in $28 \mathrm{ml}$ universal vials containing $15 \mathrm{ml}$ distilled 
(כ) әлnұедәduә| ג!

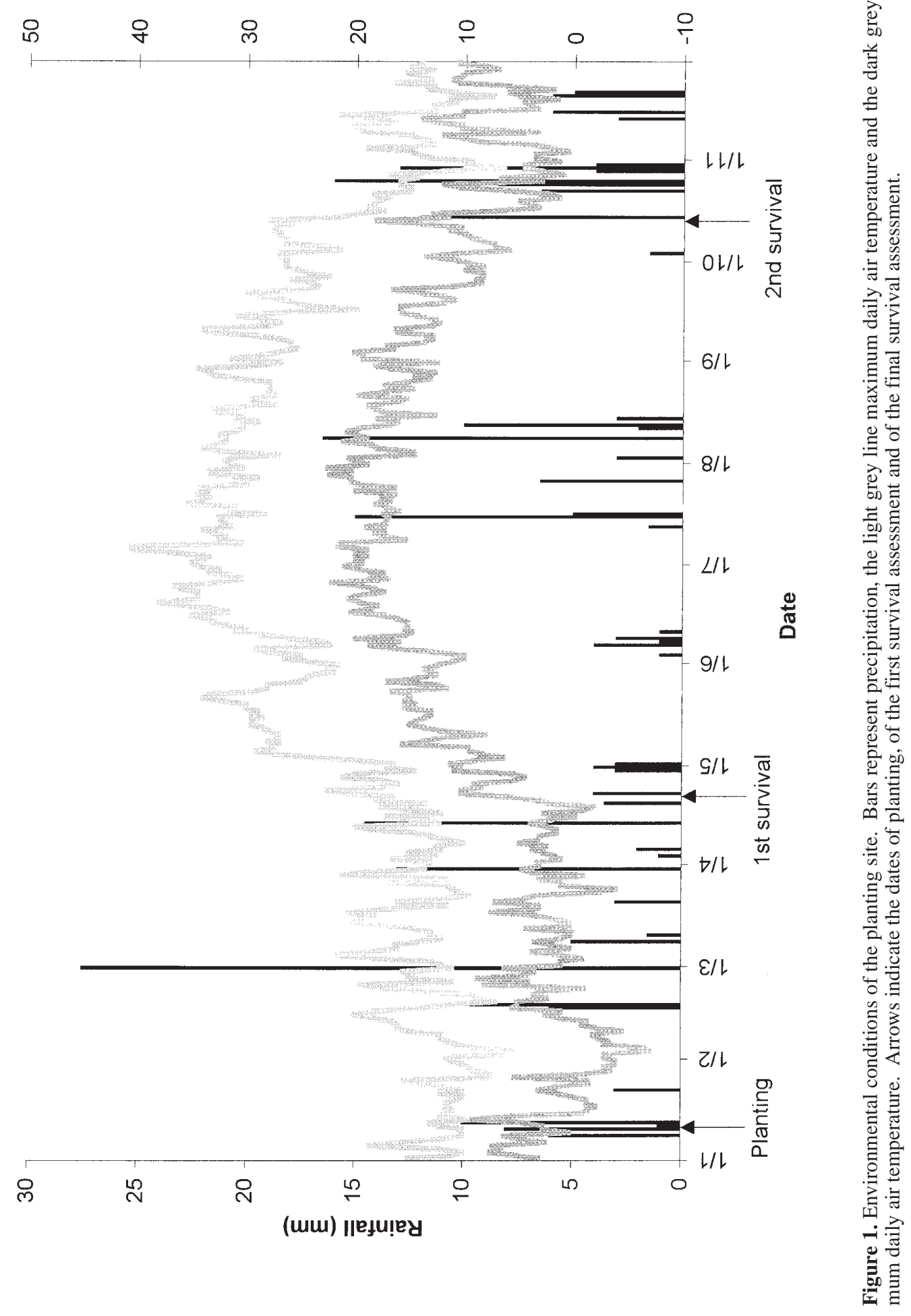


water of known conductivity $\left(C_{\text {in }}\right)$, shaken and then left at $20{ }^{\circ} \mathrm{C}$ for $24 \mathrm{~h}$. After $24 \mathrm{~h}$, the bottles were shaken again and the conductivity of the bathing solution $\left(C_{24}\right)$ was re-measured. Following the measurements, samples were autoclaved at $110{ }^{\circ} \mathrm{C}$ for 10 minutes and then allowed to cool $(5 \mathrm{~h})$; conductivities $\left(C_{\mathrm{au}}\right)$ were measured at this time. Root electrolyte leakage was expressed as: $\mathrm{REL}=\left[\left(C_{24}-C_{\text {in }}\right) /\left(C_{\text {au }}-C_{\text {in }}\right)\right] \times 100$.

Fine root water potential $\left(\Psi_{\text {root }}\right)$ was measured using a thermocouple psychrometer (Wescor Inc., USA) following the method described by Slavik [25]. In brief, small samples $(<100 \mathrm{mg})$ of fine roots from 10 plants, for each species $\times$ treatment combination, were collected and placed in thermocouple chambers and left to equilibrate with the chamber atmosphere. Then pulsed cooling currents were released for $15 \mathrm{~s}$ and the dew-point temperature was recorded.

Following desiccation or freezing, 15 seedlings, for each species $\times$ treatment combination, were taken at random and used to measure root moisture content (RMC). Samples of fine roots $(<2 \mathrm{~mm}$ diameter) were selected from midpoint of the root system, weighed (100-500 mg fresh weight) and oven dried at $80{ }^{\circ} \mathrm{C}$ for $48 \mathrm{~h}$, after which the dry weight was determined. Water content of the roots was calculated from the fresh and dry masses: $\mathrm{RMC}=[($ fresh weight - dry weight $) /$ dry weight $] \times 100$.

\subsection{Field performance}

Three replicates of 100 seedlings, for each species and treatment level, were outplanted in the Forest Research Institute's experimental field site at 15th of January 1998, in a completely randomized design $\left(40^{\circ} 35^{\prime} \mathrm{N}, 22^{\circ} 58^{\prime} \mathrm{E}\right.$, $10 \mathrm{~m}$ altitude). The site had been cultivated and weeds were controlled manually. Seedlings were shovel-planted in rows ( $1 \mathrm{~m}$ spacing between rows, $30 \mathrm{~cm}$ between plants within rows). The soil is silty loamy (45\% sand, $30 \%$ silt, $25 \%$ clay, organic matter $2 \%, \mathrm{pH}=6.5-7.0$, water holding capacity $=21 \%$ ). The mean annual precipitation is $409 \mathrm{~mm}$. No fertilization was applied. Irrigation was applied two times (mid-May and midJune) to field capacity. Air temperature and rainfall were monitored daily at the planting site (figure 1).

Percent survival was determined at the beginning (lateApril) and at the end (mid-October) of the first growing season, when plants had still leaves. Plants with no leaves or alive buds were considered as dead. Total plant leaf area was measured at the end of growing season, using a portable leaf area meter (Li-3000, Li-Cor Inc. Lincoln, NE. USA). The dry weights of the leaf, root and shoot were also measured at the end of growing season, by drying the plant tissues of a sample at $100{ }^{\circ} \mathrm{C}$ for $24 \mathrm{~h}$.

\subsection{Data analysis}

The effects of desiccation and freezing on seedlings' vitality and survival were analysed using analysis of variance (ANOVA) and, when appropriate, means were compared with Tukey's multiple comparisons tests. Percent data did not always satisfy the assumptions of ANOVA and subsequently they were subjected to the arcsine transformation for statistical analysis, but actual percentages are given in the tables and figures. Correlation coefficients between the means of vitality indicators and survival were calculated. All tests for significance were conducted at $p<0.05$, unless otherwise indicated.

\section{RESULTS}

\subsection{Effects of desiccation and freezing on plant quality}

The mean REL value of control plants was almost $20 \%$ for C. sativa and F. ornus and $33 \%$ A. pseudoplatanus (figure $2 a$ ). After $1 \mathrm{~h}$ of desiccation, REL was significantly higher than in the untreated plants, except for $C$. sativa. The highest values were observed for $F$. ornus. After $3 \mathrm{~h}$ of desiccation, REL values further increased and were different from the one hour treatment, with $F$. ornus exhibiting a REL higher than $50 \%$. All species exhibited similar high mean REL values (around 70\%), after $24 \mathrm{~h}$ desiccation.

Desiccation caused a drop to the fine root water potential in all species (figure $2 b$ ). Initial values were higher than $-1.00 \mathrm{MPa}$ in all species. Plants of all three species showed significant differences among levels of desiccation. The higher rates of changes occurred during the first 1 or 3 hours of desiccation. There were differences between species for all desiccation levels. C. sati$v a$ was most resistant to desiccation whereas A. pseudoplatanus suffered most.

Control plants of $F$. ornus and $C$. sativa had RMC values $>300 \%$, while $A$. pseudoplatanus showed a mean value around $150 \%$. Increasing the time of desiccation, reduced the root moisture content of all species (figure 2c). The highest rate of changes in RMC occurred in the first hour of desiccation. Although untreated plants of different species had different RMC values, they became similar as time of desiccation increased.

The duration of freezing at $-5{ }^{\circ} \mathrm{C}$ increased the REL values of all species, while minor changes occurred for RMC and $\Psi_{\text {root }}$ (figure $3 a$ ). Freezing for 3 hours caused a sharp increase in REL of $A$. pseudoplatanus, followed by minor but non-significant changes after 24 and $48 \mathrm{~h}$. $C$. sativa and $F$. ornus exhibited a slight increase in REL 

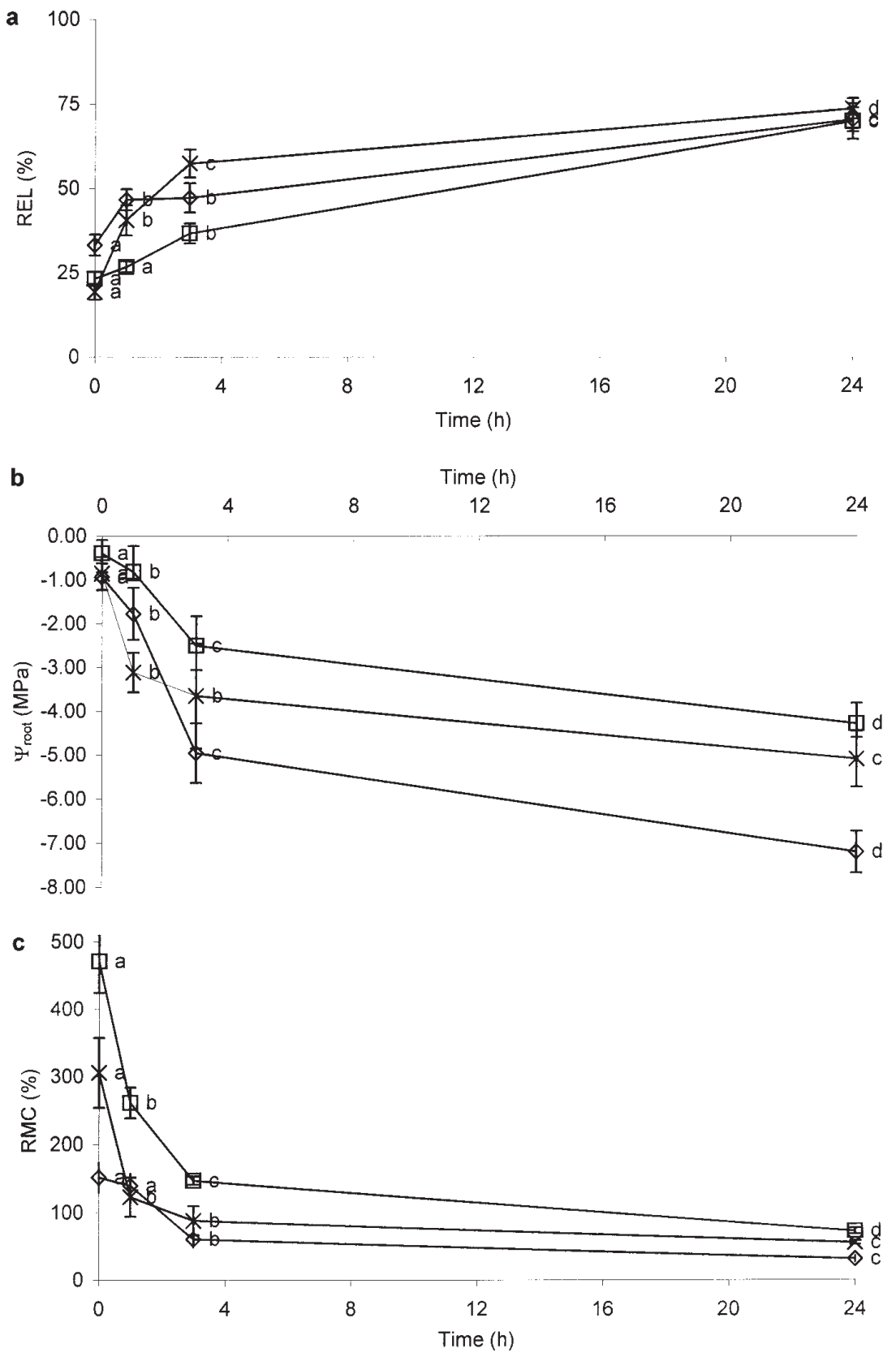

Figure 2. Effect of desiccation on vitality of Acer pseudoplatanus $(\diamond)$, Castanea sativa $(\square)$ and Fraxinus ornus $(\times)$ seedlings. Root electrolyte leakage (REL), fine root water potential $\left(\Psi_{\text {root }}\right)$, root moisture content (RMC). Data points represent means and their standard deviations. Means within the same species followed by different letters are significantly different according to Tukey's test. 


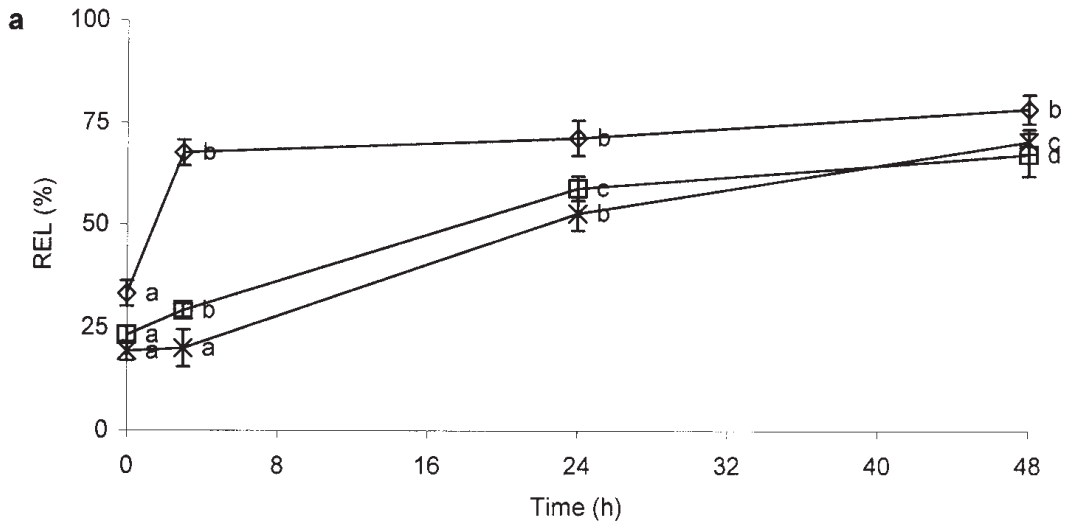

b
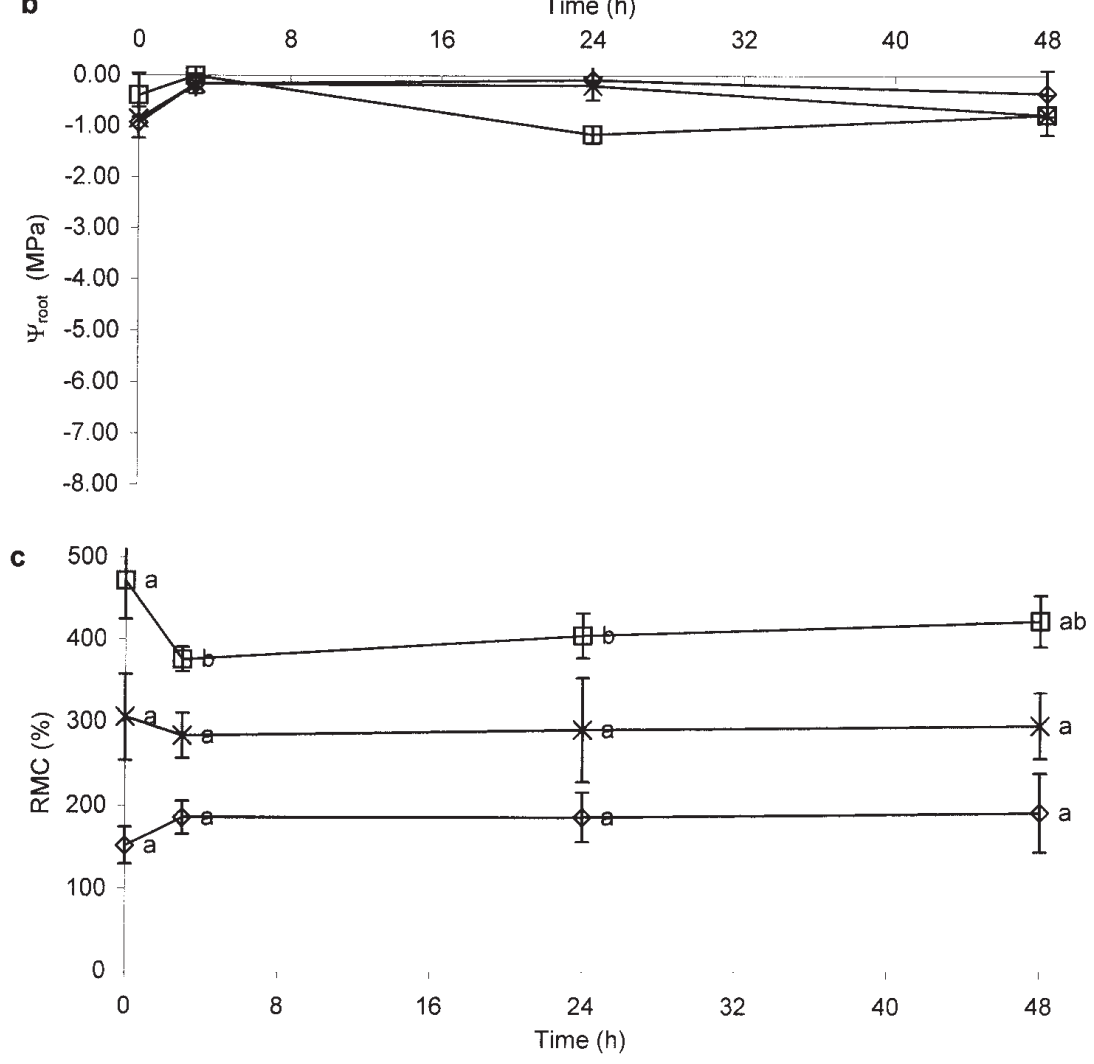

Figure 3. Effect of freezing on vitality of Acer pseudoplatanus $(\diamond)$, Castanea sativa $(\square)$ and Fraxinus ornus $(\times)$ seedlings. Root electrolyte leakage (REL), fine root water potential $\left(\Psi_{\text {root }}\right)$, root moisture content (RMC). Data points represent means and their standard deviations. Means within the same species followed by different letters are significantly different according to Tukey's test. 
after three hours of freezing followed by a relatively high rate of increase after 24 and $48 \mathrm{~h}$. After 24 hours of freezing all plants showed mean REL values higher than $50 \%$. After 48 hours of freezing all plants had a REL of almost $70 \%$, similar to 24 hours desiccation treatment. $\Psi_{\text {root }}$ and RMC of all species were unaffected by freezing treatments (figure 3b,c).

\subsection{Influence of desiccation and freezing on plant survival}

Seedling survival of all species, at the beginning of the growing season (late April), were influenced by pre-planting desiccation and freezing treatments (figures $4 a, b$ ). Control plants of A. pseudoplatanus had high mean survival $(96 \%)$, followed by $C$. sativa $(84 \%)$ and $F$. ornus $(72 \%)$. The survival of seedlings of A. pseudoplatanus and C. sativa, desiccated for 1 or $3 \mathrm{~h}$ did not differ significantly from the untreated plants while the mean survival of $F$. ornus was reduced to almost $50 \%$, significantly different from the control. Desiccation for $24 \mathrm{~h}$ reduced the survival of A. pseudoplatanus $(31 \%)$ and to a lesser degree for $C$. sativa $(45 \%)$ and $F$. ornus $(50 \%)$. Seedlings of all species exposed to freezing temperatures for various durations showed high rates of mortality, three months after planting. Seedlings of A. pseudoplatanus subjected to freezing for $24 \mathrm{~h}$ had an average survival of $31 \%$, whereas survival was $<10 \%$ for all other species. Seedlings of all species subjected to freezing for $48 \mathrm{~h}$, did not survive after outplanting, with the exception of a few plants of A. pseudoplatanus.

Plant survival at the end of the growing season was lower compared to the beginning of the season, in all species (figure 4). Most $C$. sativa seedlings of all treatments died and $A$. pseudoplatanus suffered significant reductions. Survival of $F$. ornus seedlings was also reduced but the differences between the beginning and end-of-the-growing-season values were not significant. Differences among treatment levels were evident for A. pseudoplatanus and $F$. ornus but not for $C$. sativa.

Non significant differences were observed among treatments within plant species for growth parameters measured at the end of the growing season on surviving plants, such as total leaf area, total leaf dry weight, shoot and root dry weight.

\subsection{Relationships between pre-planting assessments and field performance}

Correlation analysis between pre-planting vitality measurements and post-planting survival resulted in dif-
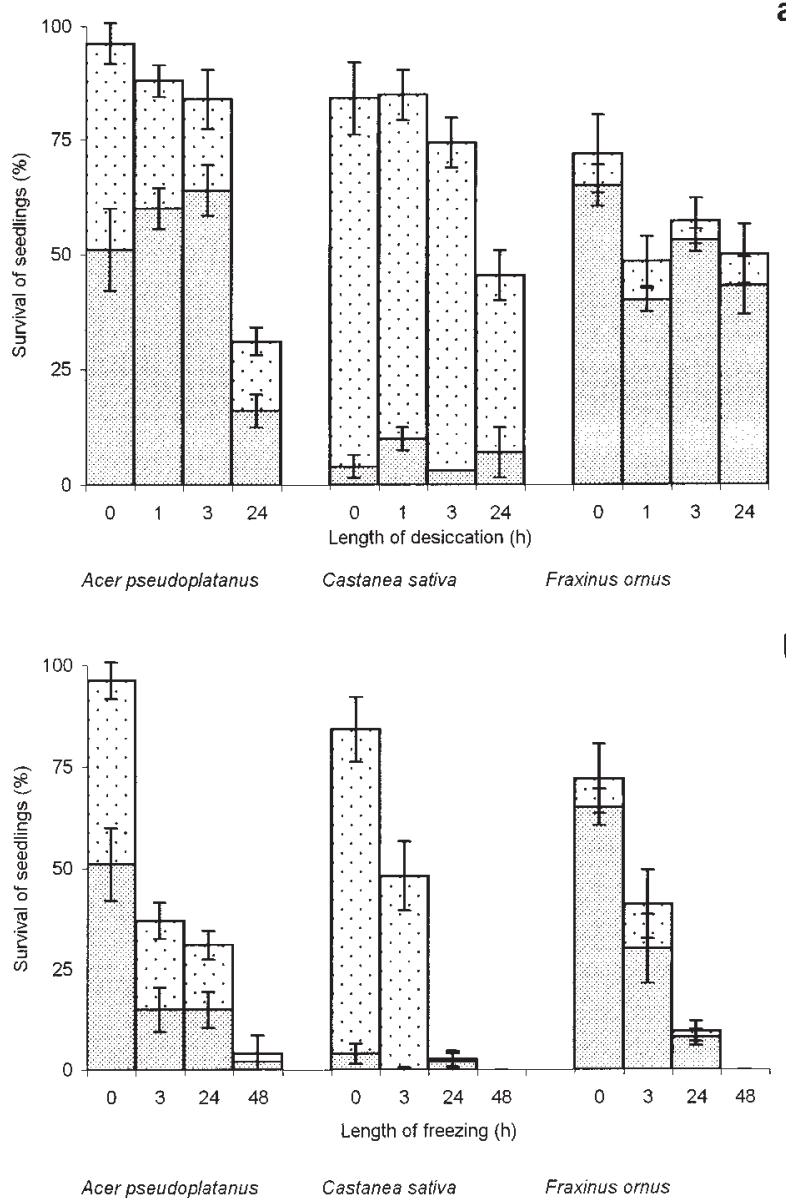

Figure 4. Seedling survival at the beginning of the growing season (dotted bars) and at the end of season (grey bars), subjected to desiccation (a) or freezing (b) treatments before planting. Bars represent mean survival and their standard deviations.

ferent correlation coefficients depending on treatment and species (table II). More significant and higher associations between all vitality indicators and plant survival were found at the beginning of the growing season compared to the end of season. REL was correlated better than RMC or $\Psi_{\text {root }}$, with survival for all plant species in both desiccation and freezing treatments. $\Psi_{\text {root }}$ correlated well with survival at the beginning of the growing season in desiccation treatments, in all species and particularly in $C$. sativa.

\section{DISCUSSION}

Overall, our results indicate that desiccation significantly affected REL, $\Psi_{\text {root }}$, RMC and survival of all 
Table II. Correlation coefficients among pre-planting vitality indicators and field performance of plants subjected to freezing or desiccation treatments. Marked correlations are significant at $p<0.05$.

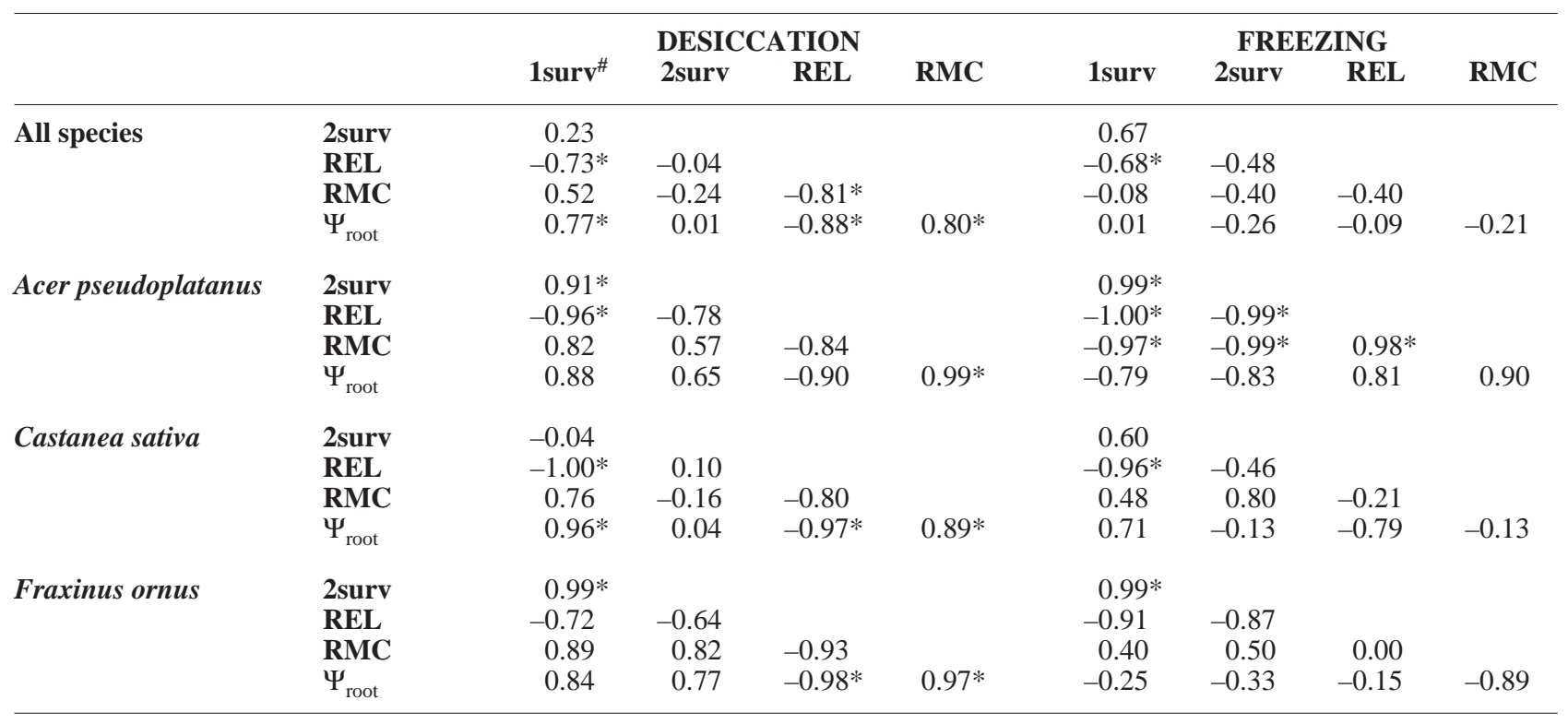

\# 1 surv = survival at the beginning of the season, 2 surv = survival at the end of the season, REL = root electrolyte leakage, RMC = root moisture content, $\Psi_{\text {root }}=$ root water potential.

species after outplanting, while freezing affected REL and survival. The effects of desiccation and freezing on planting stock quality and field performance varied and depended upon the length of exposure and species.

A main result of our study is that broadleaved tree species are prone to desiccation even during the winter period, when there are no leaves, the main transpiring apparatus of a plant. Exposure of seedlings to desiccating conditions for $24 \mathrm{~h}$ can cause a great reduction in survival and all vitality indicators. However, exposure for short durations, affected the vitality parameters in all species but survival was slightly affected only for F. ornus. Although, desiccation is considered a major threat of seedlings' vitality, exposure to moderate desiccating conditions for short periods might not be detrimental, particularly for species adapted to relatively dryconditions. Similarly, Ritchie et al. [24] found that 1-hour-long exposure of Pinus contorta and Picea glau$\mathrm{ca}$ root systems to hot, desiccating conditions had generally little effect on subsequent survival and suggested that the ability to withstand desiccation stress depends upon plant dormancy status.

Species differed in their sensitivity to desiccation. McEvoy and McKay [16] found marked differences among species in their sensitivity to fine root desiccation; Quercus robur and Fagus sylvatica were the less sensitive (REL $=10-20 \%)$, while Acer platanoides and
Fraxinus excelsior were more sensitive to desiccation $(\mathrm{REL}=40-70 \%)$.

Roots and especially fine roots are suffering or even impaired by freezing temperatures [11]. In our study, exposure to freezing conditions for 3 hours more than doubled REL values of A. pseudoplatanus while minor, non-significant, increases occurred on $C$. sativa and $F$. ornus. This species difference might be attributed to fine root tolerance to freezing. As suggested by McEvoy and McKay [15], the fine roots of certain tree species are more resistant to low temperature stress than others. McKay [18] reported damage to fine roots, assessed by REL, caused by a 3-hour exposure to sub-zero temperatures, on Picea sitchensis, Pseudotsuga menziesii, Larix kaempferi and Pinus sylvestris, and observed differences between species and provenances in frost hardiness measured as REL.

Correlation analyses were based on only 4 levels of treatment for each plant species within treatments, so only broad conclusions could be drawn. In general, REL was better related to plant survival than RMC or $\Psi_{\text {root}}$. The power of REL to detect physiological abnormalities caused by different or multiple stress factors has been underlined many times in the past. McKay and White [21] concluded that "the main value of REL lies in its ability to quantify damage caused by several stresses that seedlings might encounter between lifting and planting”. 
McKay [17] found that REL of Picea sitchensis and Pseudotsuga menziesii were highly correlated to survival and height growth after 2 growing seasons. However, Bigras [2] observed that electrolyte leakage from fine roots of Picea mariana was less well correlated with seedling survival than electrolyte leakage from the whole root system or coarse roots. From our results, it can be suggested that in many cases, REL is a reliable quality indicator and it can be applied in forest nursery practice.

The results of our experiments showed that fine root water potential could be useful in assessing damage to roots of broadleaved species where water loss occurs mainly through the fine roots. When plants are dried by the roots the loss might impose an immediate reduction in $\Psi$, but because of internal resistances, it may take time for water to move from shoot to root in response to the water potential gradient, and this might account for some of the variability in moisture content of plants with simi$\operatorname{lar} \Psi$ [27]. Coutts [4] found that root and shoot water potentials of Picea sitchensis seedlings were reduced under desiccation treatments, with root water potential being more sensitive to water loss. Bigras [2] reported that root water potential were correlated with survival of Picea mariana seedlings, subjected to freezing before planting. Girard et al. [7] concluded that for bareroot Pinus nigra ssp. Laricio var. Corsicana seedlings, needle predawn water potential at the time of transplanting was a reliable predictor of the ability to regenerate new roots and of seedling mortality after planting. Webb and von Althen [28] concluded that shoot xylem water potential may offer a useful and rapid measure of seedling physiological quality. Water potential, mainly of the shoot, is currently used as a plant quality indicator in reforestation practice. Ritchie [23] in his review on assessing seedling quality, reported that in USA, thirteen nurseries routinely measured shoot water status with a pressure chamber. Nurseries did not lift when stress exceeded $-1.5 \mathrm{MPa}$ and did not permit stress to exceed $-0.5 \mathrm{MPa}$ when grading and packing.

Our results suggest that fine root moisture content may be a simple method to detect root damage caused by desiccation. When RMC was near $100 \%$ or lower, survival was almost $60 \%$ or less. This is in agreement with values given by McKay and White [21] and lower than those given by Tabbush [27]. Coutts [4] found that the greatest reduction in moisture content of Picea sitchensis spruce seedlings exposed to drying conditions, occurred in the fine roots, showing a reduction of $70 \%$; he concluded that the performance of a plant will depend on whether water has been predominately lost through the root or through the shoot. Girard et al. [8] found that exposure to desiccation caused a progressive water loss of stem, terminal buds and taproot of Quercus rubra seedlings, and had a detrimental effect on survival and growth after planting.

The differences in numbers of alive plants between the beginning and end of the growing season could be explained only separately by species. F. ornus suffered relatively few losses during summer time probably because it is the best adapted species to the planting site conditions. A. pseudoplatanus showed significant reduction in survival and the almost complete destruction of C. sativa seedlings might be due that both species were out of their natural distribution area, although they have been planted in the area, in the past. The relatively high survival of seedlings at the beginning of the growing season was possibly dependent on stored carbohydrates. When these reserves run out, seedlings exhibited reduced photosynthetic capacity due to the drought stress, and subsequently root regeneration and elongation was limited, resulting in reduced survival by the end of the growing period.

Although no attempt was made to characterize the dormancy status of the plants used in this study, we assumed that the selected date (mid-January) corresponded to the optimal lifting time from practical experience and related studies such as McKay [20]. The seasonal study of seedling dormancy status is a prerequisite for the development of a planting stock quality optimization programme. However, no such studies have been carried out in Greece and we are not aware of related studies to the species used in our experiments.

To our knowledge, very few studies, related to plant quality indicators have been carried out in hot climates and using Mediterranean species. As McKay and White [21] found, the effect of the stock's planting condition on its subsequent growth and performance was greatly modified by the planting site. They proposed that tests of plant quality prior to planting may give information to managers of sites likely to experience dry springs while their use in sites with high spring rainfall $(>100$ $\mathrm{mm}$ per month) may be marginal. Mattsson [13] suggested that correlations between quality tests and subsequent field performance have to be established for different species and for different site and climate conditions.

Acknowledgements: We wish to thank Peter Levy for constructive suggestions on an earlier version of this manuscript. The authors are also thankful to the European Commission for having provided funds to conduct this research, supported by the FAIR Programme, contract No. FAIR1 CT95-497 and the European partners for their collaborations. 


\section{REFERENCES}

[1] Balneaves J., Menzies M., Lifting and handling procedures at Edendale nursery - Effects on survival and growth of 1/0 Pinus radiata seedlings, N. Z. J. For. Sci. 18 (1988) 132-134.

[2] Bigras F.J., Root cold tolerance of black spruce seedlings: viability tests in relation to survival and regrowth, Tree Physiol. 17 (1997) 311-318.

[3] Burdett A.N., Physiological processes in plantation establishment and the development of specifications for forest planting stock, Can. J. For. Res. 20 (1990) 415-427.

[4] Coutts M.P., Effects of root or shoot exposure before planting on the water relations, growth and survival of Sitka spruce, Can. J. For. Res. 11 (1981) 703-709.

[5] Duryea M.L., Evaluating seedling quality: Principles, procedures and predictive abilities of major tests, Oregon State University, Corvallis, 1985.

[6] Garriou D., Girard S., Guehl J.M., Genere B., Effect of desiccation during cold storage on planting stock quality and field performance in forest species, Ann. For. Sci. 57 (2000) 101-111.

[7] Girard S., Clement A., Cochard H., Boulet-Gercourt B., Guehl J.M., Effects of desiccation on post-planting stress in bareroot Corsican pine seedlings, Tree Physiol. 17 (1997) 429-435.

[8] Girard S., Clement A., Boulet-Gercourt B., Guehl J.M., Effects of exposure to air on planting stress in red oak seedlings, Ann. Sci. For. 54 (1997) 395-401.

[9] Guehl J.M., Clement A., Kaushal P., Aussenac G., Planting stress, water status and non-structural carbonhydrate concentrations in Corsican pine seedlings, Tree Physiol. 12 (1993) 173-183.

[10] Kaushal P., Aussenac G., Transplanting shock in Corsican Pine and Cedar of Atlas seedlings: internal water deficits, growth and root regeneration, For. Ecol. Manag. 27 (1989) 29-40.

[11] Koslowski T.T., Tree growth in response to environmental stresses, J. Arbor. 11 (1985) 97-111.

[12] Lindström A., Nyström C., Seasonal variation in root hardiness of container-grown Scots pine, Norway spruce and lodgepole pine seedlings, Can. J. For. Res. 17 (1987) 787-793.

[13] Mattsson A., Predicting field performance using seedling quality assessment, New Forests 13 (1997) 227-252.

[14] McCreary D.D., Zaerr J.B., Root respiration has limited value for assessing Douglas-fir seedling quality, Can. J. For. Res. 17 (1987) 1144-1147.
[15] McEvoy C., McKay H., Root frost hardiness of amenity broadleaved seedlings, Arboricultural Journal 21 (1997) 231-244.

[16] McEvoy C., McKay H., Sensitivity of broadleaved trees to desiccation and rough handling between lifting and transplanting, Arboriculture Research and Information Note (1997) 7.

[17] McKay H.M., Electrolyte leakage from fine roots of conifers seedlings: a rapid index of plant vitality following cold storage, Can. J. For. Res. 22 (1992) 1371-1377.

[18] McKay H.M., Frost hardiness and cold-storage tolerance of the root system of Picea sitchensis, Pseudotsuga menziesii, Larix kaempferi and Pinus sylvestris bare-root seedlings, Scand. J. For. Res. 9 (1994) 203-213.

[19] McKay H.M., A review of the effect of stresses between lifting and planting on nursery stock quality and performance, New Forests 13 (1997) 369-399.

[20] McKay H.M., Optimal planting times for freshly lifted bare-rooted conifers on the North York Moors, Forestry 71 (1998) 33-48.

[21] McKay H.M., White I.M.S., Fine root electrolyte leakage and moisture content: indices of Sitka spruce and Douglasfir seedling performance after desiccation, New Forests 13 (1997) 139-162.

[22] McKay H.M., Jinks R.L., McEvoy C., Effect of desiccation and rough-handling on the survival and early growth of ash, beech, birch and oak seedlings, Ann. For. Sci. 56 (1999) 391-402.

[23] Ritchie G.A., Assessing seedling quality, in: Duryea M.L., Landis T.D. (Eds), Forest Nursery Manual: Production of bareroot seedlings, Martinus Nijhoff / Dr. W. Junk Publishers, The Hague/Boston/Lancaster, 1984, pp. 243-259.

[24] Ritchie G.A., Roden J.R., Kleyn N., Physiological quality of lodgepole pine and interior spruce seedlings: effects of lift date and duration of freezer storage, Can. J. For. Res. 15 (1985) 636-645.

[25] Slavik B., Methods of studying plant water relations, Springer-Verlag, New York, 1974.

[26] Tinus R.W., Root growth potential as an indicator of drought stress history, Tree Physiol. 16 (1996) 795-799.

[27] Tabbush P.M., Effect of desiccation on water status and forest performance of bare-rooted Sitka spruce and Douglas fir transplants, Forestry 60 (1987) 31-43.

[28] Webb D.P., von Althen F.W., Storage of hardwood planting stock: effects of various storage regimes and packaging methods on root growth and physiological quality, N. Z. J. For. Sci. 10 (1980) 83-96. 